\title{
Agroforestry governance for operationalising the landscape approach: connecting conservation and farming actors
}

\author{
Yves Zinngrebe ${ }^{1,11}\left(\mathbb{1} \cdot\right.$ Elena Borasino $^{2} \cdot$ Brian Chiputwa $^{3} \cdot$ Philip Dobie $^{3} \cdot$ Edwin Garcia $^{4} \cdot$ Anja Gassner $^{5}$. \\ Phillip Kihumuro $^{6} \cdot$ Heru Komarudin ${ }^{7} \cdot$ Nining Liswanti $^{7} \cdot$ Permutia Makui $^{3} \cdot$ Tobias Plieninger $^{1,8} \cdot$ Etti Winter $^{9}$. \\ Jennifer Hauck ${ }^{10}$
}

Received: 21 December 2019 / Accepted: 10 July 2020 / Published online: 9 August 2020

(c) The Author(s) 2020

\begin{abstract}
The expansion and intensification of agriculture as well as the associated land clearing are threatening both biodiversity and human wellbeing in tropical areas. Implementing agroforestry systems through a landscape approach has a strong potential for integrating nature conservation objectives into agricultural systems. A key challenge for implementing the landscape approach is that political processes and conservation initiatives operate in 'silos', being largely disconnected from farmers and local key agents responsible for tree governance. In this study we brought together different stakeholders in facilitated, structured focus discussions to analyse the role of actor groups in tree governance. We used social network analysis to quantitatively and qualitatively analyse agroforestry governance networks and actor interactions related to information exchange, finance flows, and regulation. The analyses were conducted at national, sub-national and local levels in four countries: Honduras, Peru, Indonesia, and Uganda. Using trees on farms as a boundary object enabled all participants to bridge common interests and illuminate some of the constraints and opportunities of local governance systems while overcoming institutional and ideological barriers. The quantitative results of the social network analysis identify a strong density of actor linkages. Despite this density, results indicate incoherent and fragmented actor networks undermining the support for agroforestry on all levels. Nevertheless, existing processes related to finance, information, and regulation can be better aligned to ensure an effective implementation and mainstreaming of agroforestry for biodiversity conservation. Building social capital among key actors on both national and local levels can reveal a strong potential for adaptive learning processes mainstreaming agroforestry as essential component of "good farming" and integrating incentive systems for a coherent and effective agroforestry governance. We conclude that redirecting both public and private funding towards continuous seed-funding for the facilitation of these integrated learning processes can transform landscape management and at the same time reduce transaction costs.
\end{abstract}

Keywords Social capital $\cdot$ Adaptive capacity $\cdot$ Biodiversity $\cdot$ Aichi target $7 \cdot$ Social network analysis $\cdot$ Net-Map

Handled by José Muñoz-Rojas, Universidade de Évora, Portugal.

Electronic supplementary material The online version of this article (https://doi.org/10.1007/s11625-020-00840-8) contains supplementary material, which is available to authorized users.

Yves Zinngrebe

yves.zinngrebe@ufz.de

Georg-August-Universität Göttingen, Göttingen, Germany

2 Grupo de Análisis Para El Desarrollo (GRADE), Lima, Peru

3 World Agroforestry (ICRAF), Nairobi, Kenya

4 Centro Agronómico Tropical de Investigación Y Enseñanza (CATIE), Tegucigalpa, Honduras

5 World Agroforestry (ICRAF), Los Banos, Philippines
6 World Agroforestry (ICRAF), Kampala, Uganda

7 Center for International Forestry Research (CIFOR), Bogor, Indonesia

8 Universität Kassel, Witzenhausen, Germany

9 Leibnitz Universität Hannover, Hannover, Germany

10 CoKnow Consulting, Jesewitz, Germany

11 Helmholtz Centre for Environmental Research, Leipzig, Germany 


\section{Introduction}

Mainstreaming biodiversity conservation into agriculture is of utmost importance to reduce biodiversity loss and to enable sustainable landscape management. While governmental efforts have focussed on extending the protected area network, Aichi target 7 of the Convention for Biological Diversity (CBD) calls for sustainable agriculture supporting biodiversity and ecosystem functions, such as connectivity and habitat stability (CBD 2010). At present, however, the expansion of intensified agriculture and related land-use changes are major threats to biodiversity (IPBES 2019), often leading to conflicting interests between the different actors involved in the governance of agricultural landscapes (Laurance et al. 2014). It is the responsibility of CBD member states to develop National Strategies and Action Plans (NBSAPs) that translate the target of sustainable management of agricultural landscapes into national action while coordinating production and conservation (CBD 1992). The landscape approach bears the potential of bringing multiple stakeholders together using a common problem to facilitate a collaborative negotiation and at best a joint learning process (Sayer et al. 2013). Assuming that boundary objects can facilitate the exchange and comparison of different actors over common elements of interest (Leigh Star 2010; Schleyer et al. 2017), trees on farms forming agroforestry systems have potential to bring together actors interested in improving ecosystem stability in tropical landscapes and support local livelihoods.

Agroforestry has been defined as the combination of trees with agricultural crops or livestock in an integrated farm management (Fagerholm et al. 2016). As central element of agroforestry systems, trees can be integrated as for instance individual fruit trees or shade trees on pasture, or as patches such as woodlots and orchards or hedges to secure production and benefits to all land-users (van Noordwijk 2019; Somarriba et al. 2017; Dobie et al. 2019). Agroforestry has been promoted for its many provisioning ecosystem services that often result in diversified income sources for land users (e.g., food, fodder, timber, non-timber products) and an overall improvement of livelihoods (Kassie 2018; FAO 2005, 2019). In sub-Saharan Africa, trees account for $17 \%$ of the total gross annual income of those households (Christiaensen and Demery 2018). Additionally, in agroforestry systems diverse components are spatially and temporally arranged to mimic natural water and nutrient processes with less need for artificial inputs like fertilizers, herbicides, and pesticides, providing important regulating services, such as improvement of soil fertility, protection against erosion, water regulation and purification, biodiversity conservation, and carbon sequestration (Lorenz and Lal 2014; HLPE 2019). Their contribution to biodiversity conservation ranges from the insects that provide food for birds and pollination services to biological pest control and significantly increased diversity of soil organisms (Priess et al. 2007; Barrios et al. 2012; Dawson et al. 2013). Trees on farms also increase biological connectivity in the landscape, ensuring the integrity of protected area networks (Dawson et al. 2013). Agroforestry systems are a major contribution to the carbon pool on agricultural lands (Zomer et al. 2016). And finally, agroforestry systems are linked to cultural ecosystem services, for instance linked to traditional practices, aesthetic values, local knowledge or tourism (Jose 2009; Moreno et al. 2018; Torralba et al. 2016; HLPE 2019). Examples for common agroforestry systems range from silvopastoral systems in Honduras, to cacao associations in Peru, traditional "tembawang" agroforestry systems in Indonesia (Marjokorpi and Ruokolainen 2003), or small scale coffee farming in Uganda. In all these countries, agroforestry systems are deployed as a strategy to counterbalance an advancing agricultural frontier that causes deforestation. This corresponds with global views that consider agroforestry an essential component of landscape management, including landscape restoration (Sayer et al. 2013; IUCN and WRI 2014).

Despite the multitude of ecosystem services attributed to agroforestry systems, the potential of trees on farms remains largely invisible to both farmers and political actors (Somarriba et al. 2017; Chiputwa et al. 2020). As a consequence, responsibility for agroforestry receives little attention and is not effectively coordinated across sectors: "In principle, agroforestry is regarded as belonging to "all sectors", but in practice, it belongs to none and rarely occupies a special line in a governmental body or has its own policy space. It falls between the agriculture, forestry and environment departments, with no institution taking a lead role in the advancement of agroforestry or its integration" (FAO 2013: 10). In practice, institutional fragmentation and bureaucratic routines often undermine political coordination and integration as highlighted in the debates on climate policy integration (e.g., DiGregorio et al. 2017; Adelle and Russe 2013; Scobie 2016) and environmental policy integration (Runhaar et al. 2020; Persson and Runhaar 2018; Jordan and Lenschow 2010). Favourable actor constellations and institutional arrangements are enabling institutional learning processes to harmonise governance frameworks (Zinngrebe 2018). Moreover, cooperative actor arrangements between both governmental and non-governmental actors can offer leverage points for integrated land management (KarlssonVinkhyzen et al. 2018) and landscape governance (Oosten et al. 2018).

The social capital concept involves actors building networks of trust, exchange, and reciprocity to facilitate joint action (Rodriguez et al. 2018). While social capital does not per se lead to environmental protection, some network characteristics have been identified as supportive for collective 
action and sustainable resource governance (Meinzen-Dick et al. 2004; Ostrom 2009). Processes of developing an integrative governance system to support agroforestry systems will therefore depend on the social capital among relevant actors. Despite the need to understand individual settings in national and subnational contexts, a comparison across different case studies will help to generalise insights on governance of and for agroforestry systems (c.f. Magliocca et al. 2015).

The aim of our study is to develop an exploratory approach that compares understandings of actor collaboration, their roles and interactions in agroforestry governance, by asking the following research questions:

(1) What are structural main characteristics of the agroforestry governance networks?

(2) Which are key flows of finance, regulation, and information in the national governance networks and to what extent do they support agroforestry?

(3) Who are the key actors in agroforestry governance and how do they support sustainable transformation?

Our study is focused on agroforestry in Uganda, Honduras, Peru, and Indonesia to capture a broad geographical variation of these land-use and governance systems in the tropics. We assume that similarities in governance structures in these culturally, geographically, and technologically diverse settings will reveal important leverage points for implementing the landscape approach and harnessing the potential of agroforestry. After introducing a theoretical framework, case studies, and methodology, we present the results in response to the three research questions before discussing possible entry points for governance interventions.

\section{Analytical approach}

\section{Theoretical framework and hypotheses}

Our analysis is based on three key assumptions, derived from the actor networks and governance structures literature, regarding structural characteristics of actors networks, specific governance functions, and specific actors.

Firstly, structural characteristics of actor networks can be interpreted for the purpose of understanding sustainable transformation and innovation. Social capital assesses the inter-relationships between individuals (social networks) and related norms of reciprocity (such as trust), that give value at both the individual and the collective level, can be defined (Putnam 2004). In particular, high network densities of formal and informal links between relevant actors are a precondition for the diffusion of innovation of agricultural technology and adaptive capacity of governance networks (Saint Ville et al. 2016; Bourne et al. 2017; Bodin and Crona 2009; Pretty and Smith 2004). It is important to note that while the structural attributes of networks are important indications for actor dynamics, attributes considered important for information flow may not always be consistent with those for collective action. One network feature may in fact inhibit another and there is a need to balance often opposing structural characteristics to ensure a beneficial outcome (Duit et al. 2009; Bodin and Crona 2009). Lack of access to information is a key barrier to adoption of better agricultural technologies and farming practices (Bandiera and Rasul 2006), whereby the right combination of information from both local experience and expert knowledge is often needed for innovation creation, adoption, and adaptation (Esparcia 2014). When looking at the relationship of agricultural development and deforestation, it is not connectivity per se, but the quality of relations between main governing institutions that influence environmental performance (Bhattarai and Hammig 2004). For the exchange of information, a high reciprocity indicates trust as a basis for continuous coordination and collaboration (Hauck and Schiffer 2012). Comparative studies comparing different governance settings find that higher centrality values indicate a stronger access to information, while hierarchy and power constellations shape information flows and the nature of interactions (Schröter et al. 2018; Manolache et al. 2018). In agroforestry systems, mono-directional knowledge flows from technical experts to project managers and farmers can be a barrier to innovation as collective exploration processes are needed to find solutions responding to contexts and local perceptions (Berthet and Hickey 2018). Furthermore, while there is ample literature on local actor networks, there is a need for a better understanding of how embedded governance systems across different levels and sectors can integrate the variety of functions and actor groups to coherently support agroforestry. Thus, we hypothesise that effective agroforestry governance networks depend on high densities, connecting actors with different interests integrating production and conservation while at the same time comprising reciprocal exchange of information, both between actors and political levels.

Secondly, specific governance functions are central for an actor network to contribute to sustainable resource management (Bodin and Crona 2009). Policy frameworks and financial support are important to provide economic incentives for agroforestry practices (Ajayi and Place 2012; Pretty et al. 2011). At the same time, systemic constraints and adverse incentives are key barriers to agroforestry (Ashley et al. 2006). Bad coordination can result in a "responsibility gap" with no actor feeling accountable for implementation (Sarkki et al. 2016). Instead, "catalytic alliances" and public-private partnerships can coordinate and harmonise governance processes to a state of minimal incoherence and contradictions (Karlsson-Vinkhuyzen et al. 2017; Holg et al. 2016). Poliycentric governance research has shown that even networks with maintained strong structural densities can change in their key 
interests (e.g., away from conservation to exploitation) or also in internal configurations (Morrison 2017). The effectiveness of governance systems to safeguard environmental goals are shaped by specific modes of stakeholder coordination (Galaz et al. 2012), the ways power is executed on different governance levels (Morrison et al. 2017), as well as the provision of enabling institutional environments through leadership and commitment by governmental or non-governmental actors (Nunan et al. 2012; Karlsson-Vinkhuyzen et al. 2017). Access and exchange of information and targeted capacity building are requirements for innovation in agroforestry practices (Isaac et al. 2007; Pretty et al. 2011). Thus, we hypothesize that effective governance for agroforestry systems depends on the ability to (a) provide regulation that enables the uptake and commercialisation of agroforestry systems, (b) offer financial incentives for the implementation of agroforestry systems, and (c) support information flows that provide new information of agroforestry systems, frame knowledge processes towards agroforestry innovation, and incorporate this information into learning processes.

Thirdly, specific actors play an important role in governance networks. For instance, the way powerful actors with high levels of centrality perceive and regulate sustainable practices has a strong impact on the overall governance functions (Bodin and Crona 2009) and hence the support for agroforestry. While environmental ministries are mostly responsible for developing strategies for implementing the global target on sustainable agriculture, agroforestry is strongly influenced by other sectoral policies, such as forestry and agriculture. Transformation of agricultural practices depends on bridging actors that facilitate the integration of new knowledge into often tight local governance networks, mainly between governmental institutions and influential farmers (Saint Ville et al. 2016; Isaac et al. 2007; Bodin and Crona 2019). Particularly local governments as key actors in the governance of lands and forests have been disregarded by political agendas and need to be both empowered (e.g., in the implementation of property rights) and controlled by higher political levels (Larson et al. 2007), as they perform important bridging functions to local formal and informal farmer networks (Saint Ville et al. 2016; Sanginga et al. 2007). Our third hypothesis therefore is that key actors, such as ministries or agencies for environment, agriculture, and forestry as well as local governments and direct land-users, have to be integrated in governance network structures.

\section{Case studies}

Our study is based on eleven focus areas in four different countries that represent a range of different agroforestry systems and governance arrangements across three continents (Table 1). Within the countries, local areas with strong deforestation dynamics and potential for agroforestry were

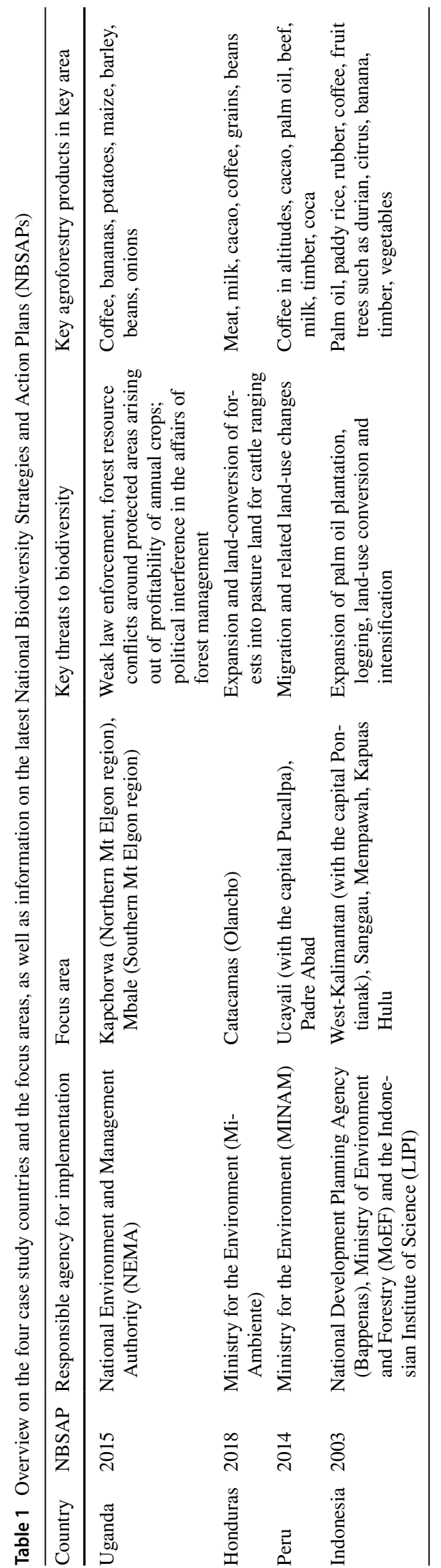


selected. In all countries, NBSAPs define biodiversity targets relevant for agricultural landscapes, but have not explicitly targeted agroforestry systems so far (Dobie et al. 2019).

\section{Methodological process}

For our participatory social network analysis, we used the Net-Map tool. The Net-Map tool is a participatory approach in which individual actors discuss, understand and visualise important and complex formal and informal linkages, power relations and the goals of each actor in the networks they participate in (Schiffer and Hauck 2010; Hauck et al. 2016). In conventional social network analysis approaches, data are collected and analysed quantitatively, based on individual responses from actors who map out their own ties to other actors in a given network. This makes it difficult to 'tease out' the underlying reasons for complex and dynamic structures (Schröter et al. 2018; Reed 2009). By contrast, NetMap builds on an on-site network visualisation by drawing networks with the interviewees to facilitate the exploration of networks and their associated meanings. While this comes at the expense of limited participants, results are improved by negotiating among participants which further allows for participant learning (Schiffer and Hauck 2010; Schröter et al. 2018; Hauck et al. 2015). The process of data collection and analysis was done in a sequential process in the period from August 2018 to November 2019 (Fig. 1).

\section{Step 1: Developing Net-Map guidelines}

To prepare for the data collection, local partner organisations implementing the Net-Map process in each country (henceforth referred to as "country teams" and authors to this paper) received methodological training to ensure comparable data collection processes. Subsequently, Net-Map guidelines were developed jointly to define a maximum of commonalities in the questions across the case studies and still adapt them to national and local contexts. The overall guiding questions were developed as well as a common terminology defining terms such as "agroforestry", "trees", "farms", as well as flow eligible as e.g. "finance flows", taking into account variations among countries and languages.

\section{Step 2: Sampling of participants}

In each of the four countries we intended to host Net-Map workshops at all political levels relevant for the governance of agroforestry systems. It was not possible to host national Net-Map workshops in Indonesia and Uganda due to organisational and financial constraints linked to the political culture of the countries. In Uganda and Honduras, we decided not to host sessions at sub-national levels as these levels do not have a specific mandate for agroforestry governance. Country teams were asked to invite six to twelve participants as experts, representing the following actor groups relevant for agroforestry governance: governmental entities, farmers' organisations, and representatives from the private sector, NGOs, academia, and finance actors, who have been working in the context of agroforestry systems (Fig. 2).

\section{Step 3: Hosting workshops}

Net-Map workshops lasted three to four hours and included the following themes: (a) eliciting influential actors and their characteristics, (b) identifying relations such as information flows, financial flows, and regulatory flows between actors by drawing links between the actors, (c) asking for the overall level of influence of actors on agroforestry (weighed in so-called "influence-towers"). Additionally, participants provided qualitative explanations for the selected actors and the types of relations that connect them. As a last step of the workshop, participants were asked to each reflect on the activity and to identify their key observation. After the Net-Map sessions, mappings of actors were translated into excel tables that cover the following information: 1. List of identified key actors, with a description of their relation
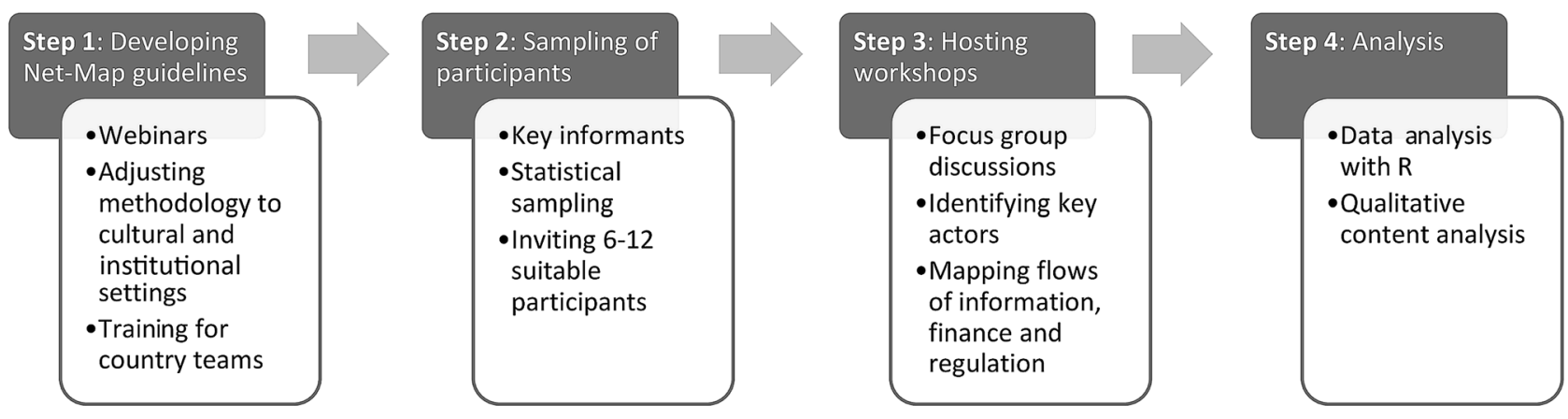

Fig. 1 Methodological approach and process of the Net-Map workshops 
to agroforestry and influence tower values, 2. Quantitative (with $1=$ link and $0=$ no link) and qualitative information on flows of information, regulation, and finance.

\section{Step 4: Analysis}

We first performed quantitative analyses to screen the data and identify key actors and flows that were subsequently explored using qualitative content analysis. The quantitative analysis for the overall network characteristics and the flows of regulation, finance and information was done according to the following characteristics: (a) Number of links per network, (b) Density of the network, i.e. the number of actual links divided by the possible links (number of actors minus one), and (c). Reciprocity, expressed as the ratio of mutual links among the actors in a network as a measure of mutual trust and an indication of social capital.

With regard to the actor groups we calculated the following values: (a) Influence of each mapped actor as assessed by participants in influence towers (standardised into values from 0 to 1); (b) Degree of centrality, referring to the number of links that an actor has, either from this actor to other actors (out degree) or from other actors to this actor (in degree). Summation of the two (in and out degree) gives the total degree for an actor. With reference to hypothesis 1 we assumed that an actor with a higher centrality than other actors has dominant position in the governance network (c) Betweenness centrality as a measure of how a particular actor connects two or more other actors that are otherwise not connected to each other. According to hypothesis 2 we assumed that an actor with a high value for betweenness centrality has a specific bridging function and can either be a gate keeper or a facilitator of a governance function.

Quantitative social network measures were computed using R Statistical Software packages (igraph, influenceR). This included the calculation of graph level measures: density, edge and vertex counts, reciprocity, graph diameter, and E-I index. Using centrality measures, key actors were identified as actors with the highest total degree, betweenness, and bridging scores. Descriptive statistics were used to summarise actor level centrality measures for each graph. We used Quadratic Assessment Procedure (QAP) to compare the similarity between finance and regulation flows (Butts 2010). The similarity of hypothetical graphs for regulation and finance graphs was simulated for each of the political levels while controlling for network/graph structure. While all of these quantitative values indicate the potential of an actor, the specific role and agency in a network was revealed by qualitative analysis.

For our qualitative analysis we selected the three actors with the highest value for each influence, degree of centrality and betweenness centrality for each case study, while assuring a representation of at least one actor of each of the predefined actor categories (Fig. 1). We then prepared country reports to extract possible explanations for the numbers explaining the role of actors and network ties based on the network transcripts. More concretely, country teams were asked to describe the role particular actors played and look at e.g.: what type of information do they distribute and/ or collect? What type of finance do they distribute and/or collect? What type of regulation do they implement? The responses from the country team reports were compared, and joint patterns across political levels, countries and individual

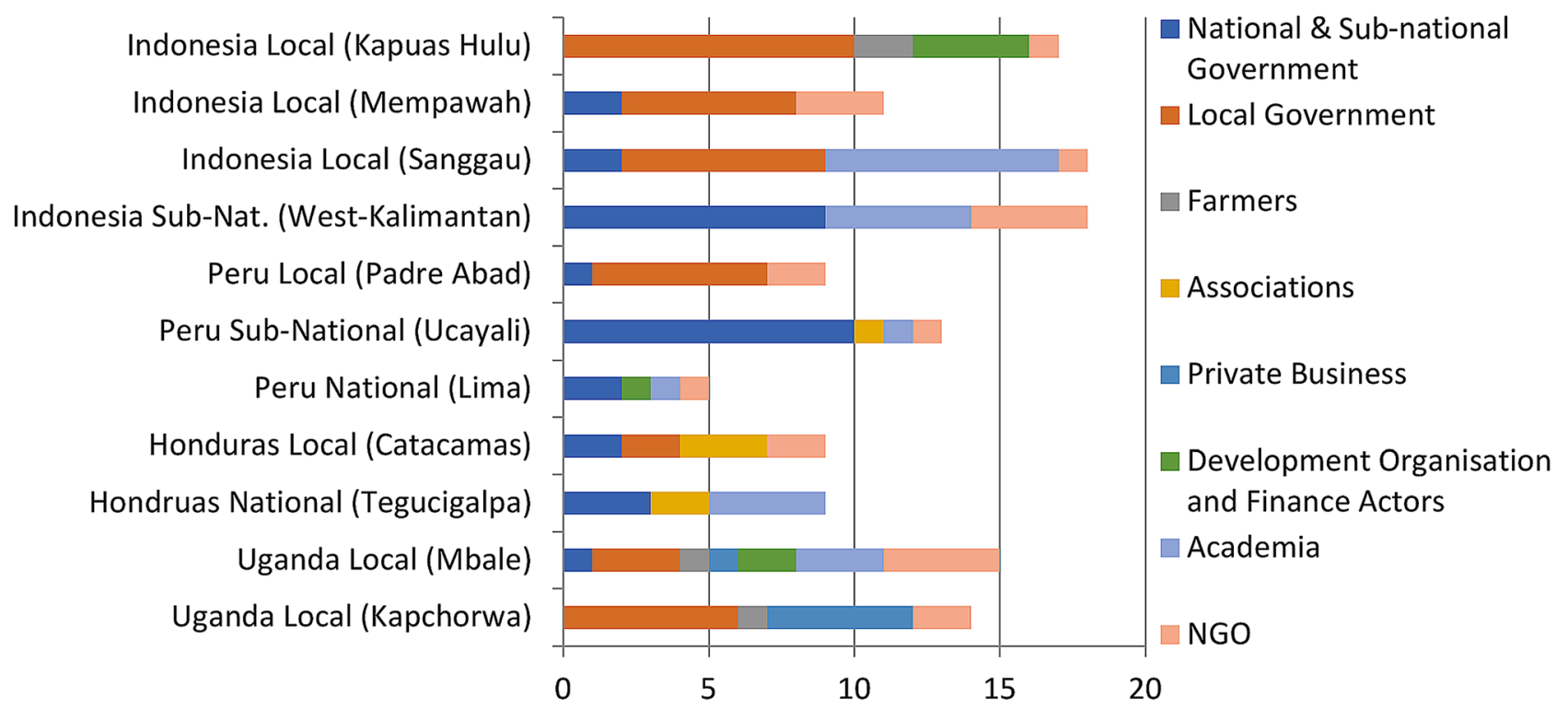

Fig. 2 Distribution of workshop participants across predetermined actor groups 
workshops were extracted and contrasted with the quantitative results.

\section{Results}

\section{General structural network characteristics}

The actor networks across the case studies showed a high density, particularly regarding the exchange of information (Tables 2 and 3, Supplementary Material 1 Figure SM1-1). Information networks were relatively homogenous without encapsulated sub-networks. In comparison density of the networks was even higher on the local level than on the national and sub-national levels. An exception was the local case of Peru (Padre Abad), where existing initiatives and actors were reported to work largely independently. Despite the generally high levels of reciprocity indicating bilateral interaction, qualitative explanations indicated that many ties consisted of simple information exchange without indicating stronger levels of collaboration. We could not detect general trends among countries or at different levels.

In finance and regulations, there were overall fewer links reported and consequently there was a lower network density. Links were also less reciprocal, as money and regulation usually flow unidirectional, e.g., from one donor to one recipient. An exception to this rule could be found in the Net-Map in Kapchorwa (Uganda). Here, governmental and financial actors exchanged finance flows as they were jointly managing farmer support. In general, we found the following finance flows in all case studies indicating the availability of funding for agricultural activities related to agroforestry. Governmental agents supported local farmers with inputs. In cases of higher reciprocities (e.g., Catacamas, Honduras) farmers also paid governmental agents e.g., for user permits. Comparing finance and regulation flows we observed similar patterns across the case studies at both local and national/provincial levels supported by QAP values (see Table 2, Fig. 3). Levels of similarity were higher within the local levels for all the case studies. With the exception of the national level in Honduras, significant levels of similarity between financial and regulation flows were noted in all the case studies. An important observation of the qualitative interpretation of regulatory links was that most interactions were relevant for tree governance, but not directly targeted at supporting agroforestry.

\section{Principal flows between actor groups}

The following section presents these patterns for flows of finance, regulation and information relevant for agroforestry governance and illustrates them with specificities from the different case studies.

Finance - repeating themes and barriers

Funding for governmental organisations and projects was administered by central Finance Ministries in all countries, including both governmental budgets and funds from development cooperation and biodiversity and climate initiatives. Accounting methodologies considering the costs and benefits of ecosystem services including those provided by agroforestry were being developed (e.g., by Finance Ministries in Peru and Indonesia), but their level of application was uncertain.

Credit schemes for farming processes were offered by rural banks or credit institutions in all countries enabling farmers to develop a business. Long-time investment periods and difficult liability conditions of remotely living farmers were central barriers for applications in agroforestry. In the case of Honduran coffee production, the producers association IHCafé secured liability of their associates and thereby facilitated the access to credits.

Public and private support and finance for farmers existed and covered specific costs for agricultural inputs, such as fertilizers or even plant seedlings. Special governmental funds were supporting agricultural projects or capacity building for example for young farmers or tree crops (in Uganda), in buffer zones of protected areas, farmers in general (Indonesia) or to non-coca agriculture in a drug-eradication programme (in Peru). While all of these support systems were important for farmers, they did not specifically incentivise agroforestry systems.

Payments for Ecosystem Services (PES) were related to agroforestry, but only applied in very limited scopes. For instance, a PES scheme funded by the Global Environmental Facility (GEF) in Uganda incentivised farmers to reduce deforestation to conserve chimpanzee forests. In Peru, the Ministry for Environment supported native communities with 10 Soles per hectare ( 3 US\$) for sustainable management of their communal forests.

Market premium payments for products with management requirements or certification provided incentives for agroforestry. An example was Chocolates Halba in Honduras, who required their Cacao to be complemented by Carbon offsets through tree management. Other examples were sustainability certification standards compensated with extra payments, for instance managed by Rainforest Alliance in Peru. As the other companies however did not request any sustainability requirements, companies were not assessed as very important with regard to agroforestry decisions.

In addition to funding opportunities, costs for tree management posed specific barriers to agroforestry systems in all countries. Costs for tree nurseries and seedlings added to ordinary farming costs related to crop seeds, fertilizers, 


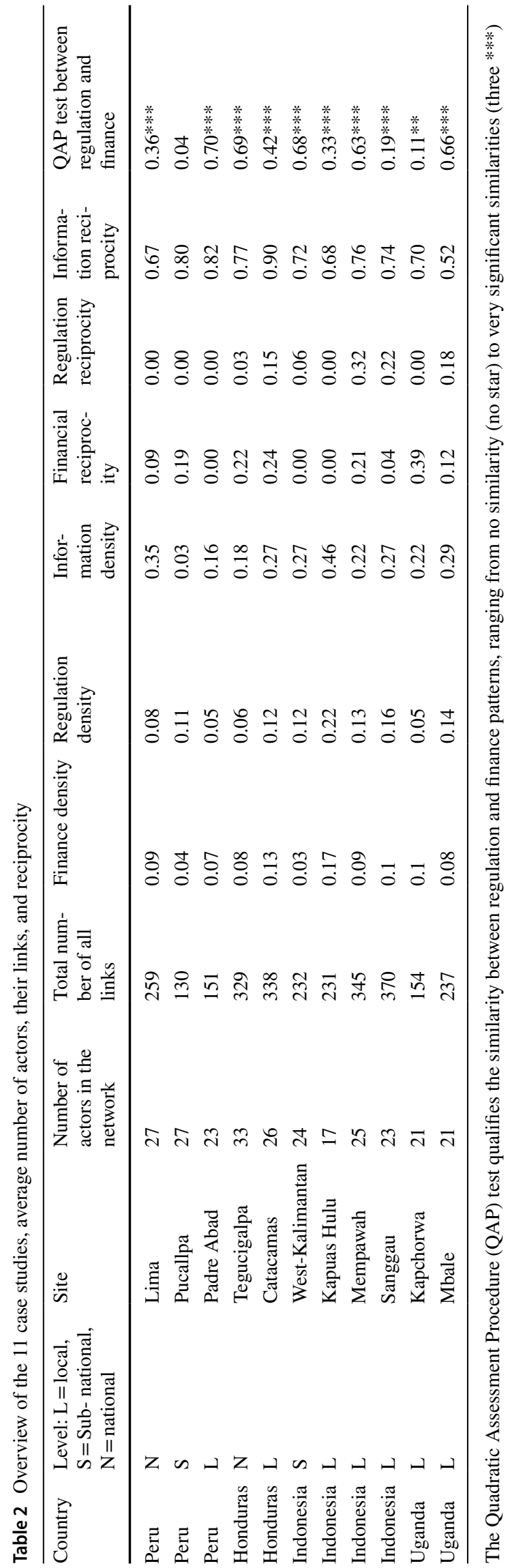

working time and pest management. While seedlings were supplied by private organisations or initiatives, costs were supported by governments, NGOs, or development organisations. In Indonesia the government supported local livelihoods by providing tree nurseries in villages in Kalimantan. Costs for membership in associations are mostly necessary to remain competitive and have market access.

Costs for commercialising timber were related to registering the trees and titling property as a prerequisite for commercialising the timber. Despite governmental support, farmers in Honduras and Peru faced costs for necessary technical assessments. Peruvian farmers could obtain agroforestry concessions for producing on state owned land. Difficulties remained with financing those leases. It was usually local governments and forestry agencies collecting payments for user permits and forestry related concessions.

Regulation - repeating themes

Regulation relevant for agroforestry schemes existed in all countries with some variations among the case studies with link densities from 0,05 to 0,22 without a specific recognisable pattern. As visible in Fig. 3 and Table 2, regulation and finance links followed similar patterns, indicating that many regulations such as permits or concessions were conditioned on payments, or that for instance buyers of products had regulatory power by demanding product or process standards.

Land-titling and land-use rights were a prerequisite to legally accessing forest and timber resources and were a strong challenge for agroforestry in all countries. In Peru, land titles could be received when an agricultural use was demonstrated to the responsible regional Agricultural Agency. Likewise in the other countries, land titles were either administered by agricultural agencies, or in case of Indonesia by the Land Agency. By contrast, regulations related to forestry and forest concessions were treated as a separate policy field in all countries. In Peru, agroforestry concessions enabled production on state owned land while requiring conservation activities. Environmental Impact Assessments on large agricultural projects required approval by the Ministry for the Environment in both Peru and Uganda. In Honduras and Uganda, regulation was designed to protect slopes and watersheds from agricultural expansion and deforestation. In Indonesia, social forestry policies incentivise the transformation of monoculture plantations such as coffee into mixed plantations. All those policies however presented strong shortcomings in implementation and enforcement. E.g., in Honduras private property and production of inter alia coffee and beans could be found inside protected areas, and on slopes. In Uganda, tenure regulation was unclear.

Registration of trees for commercial use was required to assure that only planted trees and no wild trees were cut for formal timber production. This required documented 
Table 3 Characterisation of all actor types aggregated, ranked according to their degree centrality and assessed across the 11 Net-Map cases (4 case studies were conducted on national and sub-national levels, 7 on local levels)

\begin{tabular}{|c|c|c|c|c|c|c|c|c|c|}
\hline Actor category & $\begin{array}{l}\text { Local } \\
\text { govern- } \\
\text { ment }\end{array}$ & Associations & Farmers & $\begin{array}{l}\text { National/ } \\
\text { subnational } \\
\text { goverment }\end{array}$ & Academia & $\begin{array}{l}\text { Development org. } \\
\text { and finance actors }\end{array}$ & NGO & Private business & Illegal actors \\
\hline $\begin{array}{l}\text { \# of actors in all } \\
11 \text { cases }\end{array}$ & 34 & 18 & 21 & 63 & 15 & 24 & 24 & 36 & 5 \\
\hline $\begin{array}{l}\text { \# of actor category } \\
\text { in all } 11 \text { cases }\end{array}$ & 9 & 6 & 9 & 11 & 8 & 10 & 10 & 9 & 3 \\
\hline \multicolumn{10}{|l|}{$\begin{array}{l}\text { \# of actors (out of } \\
\text { 4) mentioned }\end{array}$} \\
\hline $\begin{array}{l}\text { on national and } \\
\text { sub-national } \\
\text { levels }\end{array}$ & 2 & 3 & 2 & 4 & 4 & 4 & 3 & 3 & 1 \\
\hline $\begin{array}{l}\text { \# of actors (out of } \\
7 \text { ) in category } \\
\text { mentioned on } \\
\text { the local level }\end{array}$ & 7 & 3 & 7 & 7 & 4 & 6 & 7 & 6 & 2 \\
\hline $\begin{array}{l}\text { Influence across } \\
\text { all } 11 \text { cases }\end{array}$ & 0.46 & 0.39 & 0.58 & 0.34 & 0.39 & 0.45 & 0.42 & 0.23 & 0.25 \\
\hline $\begin{array}{l}\text { Influence across } \\
\text { all cases, where } \\
\text { category was } \\
\text { mentioned }\end{array}$ & 0.62 & 0.71 & 0.74 & 0.54 & 0.54 & 0.52 & 0.48 & 0.28 & 0.92 \\
\hline $\begin{array}{l}\text { Influence (only } \\
\text { national cases) }\end{array}$ & 0.56 & 0.82 & 0.76 & 0.53 & 0.59 & 0.73 & 0.65 & 0.47 & 0.89 \\
\hline $\begin{array}{l}\text { Influence (only } \\
\text { local cases) }\end{array}$ & 0.56 & 0.50 & 0.68 & 0.53 & 0.49 & 0.29 & 0.37 & 0.20 & 1.00 \\
\hline $\begin{array}{l}\text { Degree of central- } \\
\text { ity }\end{array}$ & 0.46 & 0.40 & 0.38 & 0.38 & 0.29 & 0.28 & 0.28 & 0.19 & 0.08 \\
\hline $\begin{array}{l}\text { Betweenness } \\
\text { centrality }\end{array}$ & 0.25 & 0.30 & 0.31 & 0.25 & 0.08 & 0.12 & 0.10 & 0.07 & 0.10 \\
\hline
\end{tabular}

The rows marked in italics are further specified into level and country values in supplementary material 2

property over the land, where the trees were registered. The local focus group in Honduras indicated problems with the knowledge of farmers about these processes, transaction costs (compiling the information, learning how the process works) and a weak complementarity of the governmental actors involved in this process.

Process and product standards were defined and supervised by Agricultural Ministries. They were (still) primarily focused towards quality and sanitary standards (e.g., for milk or meat processing).

Technological permits were usually handled by local authorities. In Honduras for instance, the local environmental agencies gave out permits for using chain-saws.

Regulatory functions of non-state actors were considered as having a strong impact on agroforestry management. The conditions of credit schemes or standards in value chains were seen to have a strong regulatory function on farmers' practices.

Information - repeating themes and barriers

The coordination between governance actors were the motivation for some of the information flows in all countries. Environmental ministries informed other ministries on their policies and collected and disseminated information on their topics. For example, forestry agencies collected and provided information on trees, forest concessions, and restoration projects. Although reciprocity between actors was generally high, participants indicated that this did not imply that actors coordinated their activities.

Capacity building on agricultural practices existed in all case studies and was related to projects or specific instruments. Usually the ministries and agencies for agriculture or forestry provided extension services and trained farmers in tree and forestry regulation. In the cases of Peru and Indonesia, this function was taken over by subnational or local agencies. In the studied cases, integrating trees and biodiversity with agricultural practices was not part of this capacity building. Additionally, private businesses informed local stakeholders on market requirements and trained them in certification and best practice requirements. For some projects, academic actors of NGOs 

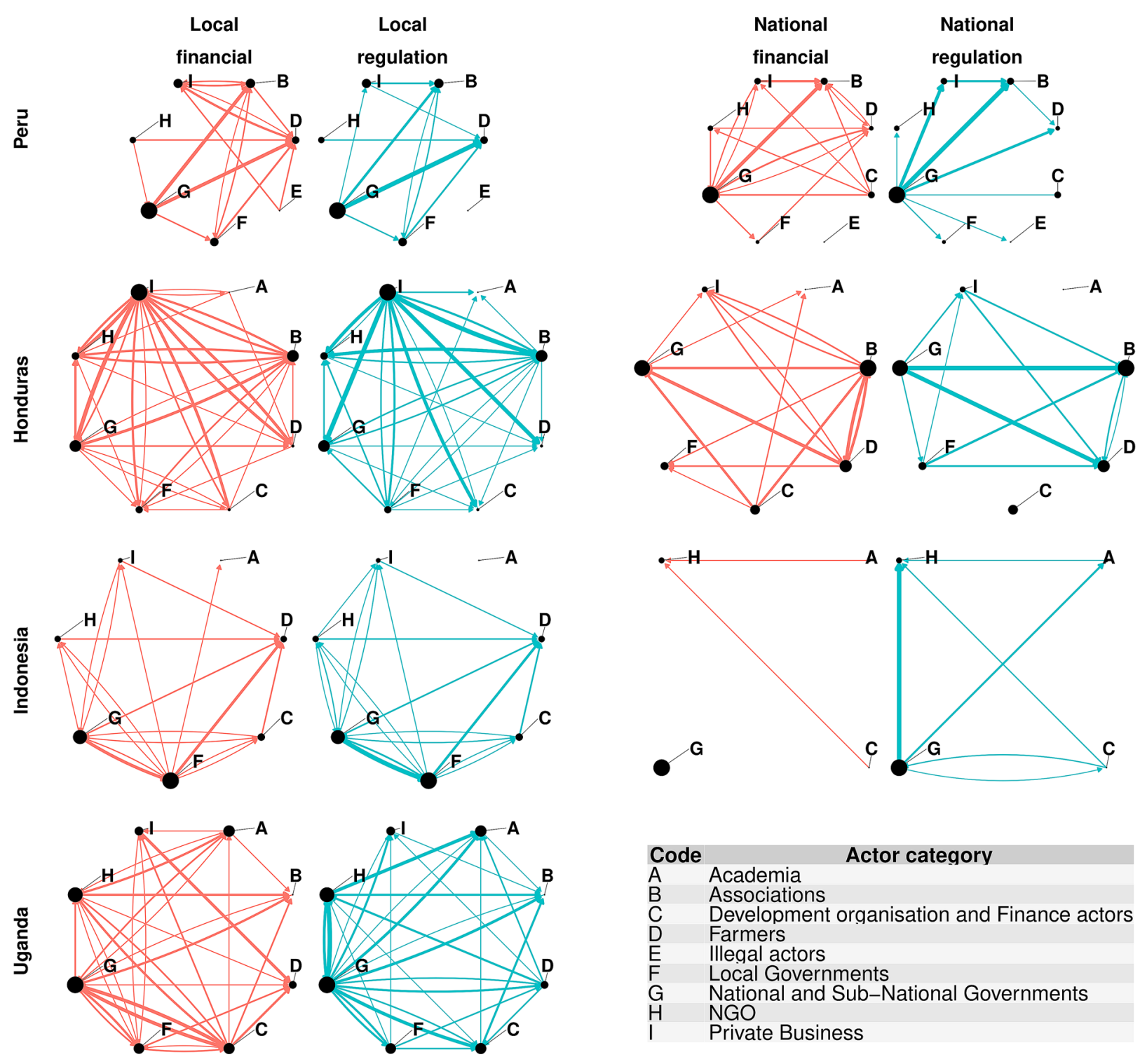

Fig. 3 Governance networks in all case studies with aggregated links for regulation and financial flows

facilitated this coordination and disseminated of knowledge related to agroforestry management.

\section{Identification and characterisation of key actors for agroforestry governance}

Based on the influence tower ratings and the number of links between actors we assessed the actor groups and ranked them according to their degree of centrality (see Table 3 and Supplementary Material 2 for detailed results). The following paragraphs present each actor group and explain its governance function.
Local governments were mentioned less often (particularly in national and sub-national Net-Maps), but rated as very influential when they appear. Both the high degree of centrality and betweenness indicated their role as a facilitator in local networks. A high value for betweenness centrality for local governments in national and sub-national NetMaps (0.35) identified local governments as important link to local networks, while their low level for degree of centrality indicated their lower integration into national and subnational governance settings. While the national government designed policies and guidelines, sub-national and district governments directly assisted communities formalising tree 
planting permits and administering policies. In Indonesia, tree planting was promoted through social forestry schemes. In Indonesia, Uganda and Honduras, the local governments and municipalities directly implemented property rights, forestry permits and licences for cutting trees to farmers and carpenters. In Peru, municipalities implemented specific public investment projects related to agricultural production.

Farmer associations represented farmers and executed important governance functions in the two Latin American countries. This influence was particularly important on local levels, where they assumed functions of gathering the products for national or international sales, reflected by higher values for degree and particularly in betweenness ( 0.45 compared to 0.22 nationally). Their influence varied as some product chains (e.g., coffee, cacao, and palm oil chains were organised more strongly) whereas others (particularly cattle raising and timber production) were rather executed individually.

Farmers and farming groups were considered as the most important actor group as they decide about tree management on their land and along riparian reserves ensuring connectivity. This was confirmed by highest value for influence and betweenness and a strong degree. A high degree on the local level ( 0.40 compared to 0.31 nationally) and a stronger local betweenness ( 0.34 compared to 0.22 nationally) highlighted a stronger integration into networks than on national and sub-national levels. Perceived accountability of farmers was therefore regarded as central for successful policy implementation. In consequence, finance flows as well as information and regulation ties densely connect farmers with most governance actors.

National and Sub-national governments had a uniform high level of influence across countries and political levels, confirmed by high degree and betweenness values. Their specific function depended on the respective sector.

Ministries for Agriculture defined process standards for agricultural production and regulated the land titling process with potentially strong effects for agricultural management, endorsing mostly agricultural expansions and intensification of monocultures (e.g., palm oil production in Indonesia, Peru and Honduras and sugarcane growing in Uganda). The Ministries for Agriculture informed on agricultural markets and trained lower governmental agencies and farmers, and approved major agricultural projects.

National forestry agencies (or corresponding Ministries) regulated forest land (e.g.: against encroachment) and implemented forest related policies, such as use concessions and forestry management plans. They also collected fees for concessions and permits for forest extraction. Forestry agencies planned, implemented, and monitored reforestation processes in all countries. They either financed seedlings production and distribution (e.g., Uganda) or directly provided them (e.g., Indonesia). In Indonesia, the ministry had a full control over forestlands and could allocate lands for nonforestry purposes (including agriculture), social forestry, or other interventions.

Ministries for Environment implemented environmental policies and projects, and coordinated with other political actors. They were the main implementers of international money channelled through global environmental agreements (e.g., Convention on Biodiversity and Framework Convention on Climate Change). National determined contribution and climate bound development cooperation instruments pushed reforestation and conservation onto sector agendas and thereby highlighted interdependencies of climate and biodiversity policies. In Peru and Uganda, Environmental Ministries approved Environmental Impact Assessments on large agricultural projects. On the local levels, Ministries for Environment were only scarcely visible through specific conservation projects or policies, such as the "Building Resilient Communities, Wetland Ecosystems and Associated Catchments" in the Uganda Project.

Ministries for Finance were not directly present on regional or local levels, but they still had an important function by steering finance flows. They financed governmental institutions, but also decided on conditions for the approval of governmental projects and international official development assistance (ODA). In Uganda, a special fund was designed by the Ministry for Finance and managed by the Bank of Uganda to provide agricultural financing to farmers and youth through commercial banks at a subsidised rate.

National park agencies engaged with farmers and communities around protected areas and provided financial support and information on reforestation in buffer zones. For instance in Uganda under the wildlife law, the park agency was expected to remit $20 \%$ of the gate collections from tourism to the neighbouring communities for "environmental and restoration related" projects. In Kalimantan (Indonesia), provincial environmental agencies engaged local population in tree planting and conservation programmes.

In Peru and Indonesia, functions of the ministries for agriculture and forestry were implemented by their counterparts on the regional level. In Peru, forestry agencies responded to the Ministry of Agriculture, while in Uganda and Indonesia they were independent sectors. In all countries, forestry and agriculture were however treated as independent policy fields, leaving agroforestry systems in a grey zone in between.

Academic actors mainly provided knowledge on farm practices, but also disseminated knowledge to political actors, train farmers and delivered tree seedlings. Furthermore, academic institutions facilitated contacts between governmental initiatives and farmer groups and planned and implemented projects, including on agroforestry.

Development organisations and financing actors were attributed a strong potential for supporting agroforestry. 
Their attested influence on the national levels (0.73) strongly superseded the value perceived on local levels (0.33) As one sub-group of this category, international cooperation, such as USAID, GIZ, UNEP etc. usually implemented their funds through direct national partner organisations, such as the Ministry for Environment, Ministries, other state agencies or NGOs. Other finance actors, such as banks or credit institutes rather focused on businesses, associations or single farmers. These actors appeared in almost all Net-Maps and especially at the national level, they were regarded as influential. Their comparatively low centrality, i.e. low degree and betweenness could be explained by them targeting, few primary partners.

NGOs played a critical role in catalysing tree planting and biodiversity conservation programmes, and in empowering farmer groups, particularly recognised on the national level (influence value of 0.65). Non-state actors proactively filled the gaps and implemented the state's roles and functions, shifting the types of function that were once the sole domain of the state.

Private businesses showed intermediate values for influence towers average degree and betweenness. Similar to developing organisation and finance actors, their influence was weighed much stronger on the National and sub-national level ( 0.47 compared to 0.21 locally). Participants in NetMap sessions highlighted the potential of those actors to exceed tree management standards, when buying agricultural products. Carpenters and timber processing agents had specific roles in the commercialisation of timber. In Peru the informal market also included charcoal producers and carpenters. They bought timber from individual farmers and timber processing agents, and they also bought and sold timber between them.

Illegal actors were scarcely identified, but showed a very high influence when they appeared. Low degrees of connectivity and betweenness resulted from links being difficult to track. Furthermore, participants felt uncomfortable talking about this topic. Illegal production (e.g., coca in Peru) competed with other types of production and light transport weight, and high prices facilitated both logistics and profitability. At the same time, anti-drug campaigns in Peru were a major source of support for other agriculture replacing drug production.

\section{Discussion}

Shedding light on governance structures in four countries, our results revealed clear entry points for a better support for agroforestry in tropical countries as a means to implement Aichi target 7. Independent of the professional background, all Net-Map participants could relate to agroforestry, revealing its potential as a boundary object. While our social network analysis does not claim to identify and assess all governance processes relevant for agroforestry, clear tendencies and similarities were identified across the four countries.

\section{Structural characteristics of actor networks}

The analysis of the main structural characteristics identified strong established networks with a high degree of connectedness for information, but also for regulation and finance flows. The absence of general network patterns among countries and levels affirmed the need for adjusting policy and finance solutions individually to given institutional settings (McAllister et al. 2015). Nevertheless, the qualitative results indicated that finance, regulatory, and information flows were not complementary, but more fragmented than the quantitative results suggest, which limits the applicability of our first hypothesis. The local levels generally showed a stronger density than higher levels. Despite the strong densities, a responsibility gap between sectors and political levels leaves agroforestry in a grey zone of governmental regulation, with no clear assigned accountabilities (Sarkki et al. 2016). Countries assign forestry to one, agriculture to another ministry, with agroforestry being in an undefined territory in between. For example, in Indonesia, tree regulation by the Ministry of Environment and Forestry is focused on state land. Being responsible for the regulation of private and agriculture lands, the Ministry for Agriculture and local governments tend to steer land use to seasonal crops without trees. In all case studies, agricultural ministries (and their provincial counterparts) had a strong influence on regulation and on extension services building local capacities on best practices for farm management, while ministries for environment as responsible agents for NBSAP implementation were disconnected from such implementing institutions. Comparing national and sub-national with local actor networks (see Table 3 and Fig. 3) revealed very different actor configurations. Thus, the fragmentation of governance processes (vertically and horizontally) for agroforestry were a strong barrier for mainstreaming biodiversity into productive sectors (Nunan et al. 2012). Key elements for governance structures supportive of agroforestry are: a targeted collaborative setting taking into account the broader institutional setting (Pavoola et al. 2009); a clear discursive and institutional framing and streamlining of agroforestry as component of "good farming" (Berthet and Hickey 2018; Ashley et al. 2006); and external bridging ties for introducing new technologies (Isaac and Matous 2017). Moreover, a stronger formalisation of the agroforestry support network might be an option to manage vulnerability of organisational tensions and unreliable external influences (Galaz et al. 2012). The strong variation of governance networks perceived by national/sub-national and local participants (visible in Fig. 1 
and Appendices 1 and 2) point to a potential for strengthening vertical ties between political levels.

\section{Specific governance functions revealed by network ties}

Key flows of finance, regulation, and information existed in all case studies and revealed a strong potential for agroforestry support. Finance flows existed even in the poorest countries, providing incentives to farmers for certain agricultural practices and thereby also executing regulatory functions. This resulted in a strong interdependence of regulation and finance flows (Fig. 3, the exception of the national level in Honduras can be explained with limited time to map all ties between a large number of actors). Our second hypothesis was however undermined, as incentive systems do not yet support agroforestry as part of general agriculture. Specific support schemes for agroforestry are scarce and have a limited scope in terms of geographical area (e.g., payment for ecosystem schemes in Uganda in biodiversity hotspots; agroforestry concessions on state forest in Peru) and target groups (e.g., social forestry in Indonesia in state owned forests and communal cooperatives, leaving private agricultural land outside of its scope). Hence, while political mandates for restoration (for carbon sequestration as indicated in nationally determined contributions) and biodiversity conservation (as indicated by NBSAPs) exist, policy integration is undermined by a missing operationalisation into local implementation processes (Persson and Runhaar 2018, Zinngrebe 2018). By contrast, general agriculture was supported in all countries by bank loans, product certification, and support schemes for agricultural development funded by governments, NGOs, or development cooperation (e.g., through anti-drug campaigns in Latin America). Instead of providing preferential conditions for agroforestry activities, however, long-term periods of tree cultivation, missing follow-up financing for tree management, and difficult liability conditions for small farmers deter investments in agroforestry. While different forms of commercialisation of timber and other tree products provide a central incentive for agroforestry (Sears et al. 2018), costs for certification, tree planting, and conservation or tree registration can deter farmers' engagement in agroforestry practices. Especially difficulties in registering trees for commercialisation and problems with land titling pose important barriers to agroforestry and favour other forms of agricultural production (Bennett et al. 2018). In this regard it is apparent that the influence of finance actors and private business are perceived as much more important on national than on the local level. It is the interplay of financing opportunities, regulatory obstacles, social infrastructure, and available information and knowledge that determines the economic viability of sustainable agriculture (Pretty et al. 2011). In this perspective, agroforestry systems have to compete with other agricultural systems, including illegal and informal activities, leading to profitability concerns (Valdivia et al. 2012) while favouring other types of agricultural production (Wilson and Lovell 2016). Sustainable value chains or companies that exceed the provision of carbon credits or certification can be an important opportunity. With the prospect of new finance opportunities from sustainable value chains or international finance instruments, such as REDD + (Catacutan et al. 2012), possible incentives for agroforestry will depend on the coordination of climate and biodiversity policies, as well as the integration of institutional settings converting those finance flows within existing governance structures while reducing administrative hurdles. Giving agroforestry an "institutional home", providing enabling conditions (van Noordwijk et al. 2019) can only be provided by an integrated governance and the enabling social capital among different governance agents.

\section{Specific actors and agency in agroforestry governance}

As key actors for agroforestry governance, farmers play a central role, as they eventually decide on whether to integrate trees into their agricultural land or not. Despite the strong influence attested to farmers and farmer associations on all levels, their strong values for degree centrality and particularly betweenness centrality points to important network functions (e.g. potentially as facilitators or as gate keepers of projects) that have to be taken into account throughout implementation processes. Particularly the two Latin American cases showed that associations can be important facilitators in this process. Local governments were regarded as particularly important in coordinating local networks and facilitating knowledge inputs from the outside, as shown by various other studies (Isaac et al. 2007, Larson et al. 2007). It is striking that farmers and local governments did not appear some of the national Net-Maps. In contrast to the strong presence of governmental actors for instance in Indonesia, we observed that NGOs, academia, and private businesses take over many governance functions. Groups of carpenters or local sawmills are hubs for the commercialisation of timber. Therefore, pilot projects with those actors on the commercialisation of timber could have strong impacts on farmers' willingness to invest in trees. In this regard it is apparent that the influence of finance actors and private business are perceived as much more important on national than on the local level. In general, local governance structures are key to implementation and - as visible by the low representation on national and sub-national Net-Maps - off the radar of many national policy processes. While key agencies, governments and farmers are included in governance networks following our third hypothesis, it is particularly 
the constellation, cooperation and political mandate of key actors that undermine a coherent incentive system as also found by the debates on biodiversity, environmental, or climate policy integration (e.g., Adelle and Russel 2013; DiGregorio et al. 2017).

It was apparent in all case studies that the environmental and responsible agencies for implementing national biodiversity targets are disconnected from implementation processes in farm management. Instead of building new mechanisms and institutions for environmental governance, a strategy of facilitating the integration of existing institutions in related sectors (e.g., forestry and agriculture) and local governance structures seems most promising. Knowledge and awareness of existing governance structures can serve as a key input to learning processes, adapting the network structure and functions to the needs of solving sustainability challenges, such transforming agricultural landscapes (Lang et al. 2012; Zinngrebe 2018). Our results indicate that currently the exchange between different governance actors is mostly restricted to informing (and potentially consulting) other agents about the own processes. Networks and platforms, such as the forestry commission COCONAFOR in Honduras, the business platforms EADEN in Uganda, or watershed forum in Indonesia could be used to better coordinate governance structures to support agroforestry processes. Experiences have shown how the engagement of governance actors in specific projects can lead to general institutional reconfigurations (Karlsson-Vinkhuyzen et al. 2017). Currently, development and finance organisations (including anti-drug programmes) mostly interact with one partner organisation, which bears the risk of producing isolated activities or projects without an impact beyond the project period. Instead, our findings support the call for multi-sector, multi-level collaboration for the implementation of the landscape approach (Axelsson et al. 2011). While land-use conflicts will emerge, the way those conflicts are managed will determine whether they can be converted into sustainable change (Sanginga et al. 2007), and thus induce learning processes towards a stronger support for agroforestry innovation in agricultural landscapes.

\section{Limitations and outlook}

The Net-Map tool is known for its benefits in co-producing knowledge, useful for both the scientists and practitioners involved (e.g., Hauck et al. 2016; Lelong et al. 2016). Consistently, participants of the Net-Map sessions strongly engaged and gave rather positive verbal feedback after the session. The tool showed potential to support the negotiations between different stakeholder groups and jointly take decisions and identify leverage points for. governance.

Despite the good atmosphere and interesting insights, participants felt that the sessions were time consuming, and some felt fatigue after the sessions. This implies a risk that not all actors and interactions are captured in the net-map charts. A possible solution would be to conduct the weighting first and only continue the exercise with the 15-20 most important actors. This approach, however, would reduce the reflexive process, in which participants become aware of actor functions they did not relate to agroforestry governance in the first place. While aiming at a representation of all relevant stakeholder groups, we had to work with those stakeholders attending our workshops. In many of the cases the representation of governmental participants was strong, probably creating a bias towards the role and influence of governmental actors with respect to agroforestry.

With a limited number of focus groups and represented stakeholders, our approach cannot map all important governance processes as it is restricted to the perspective and experience of participants. However, similarities among the case studies and the negotiation among actors with different backgrounds during the focus group sessions enabled us to identify and characterise some key opportunities and barriers in agroforestry governance. Future research is needed to have a closer look at individual processes while still considering interdependencies among actor structures and their complementary governance functions. As the true complementarity and cooperation between governance processes appears to be a key limitation in agroforestry governance, more research is needed on enabling conditions for cooperation and the potentials of actor platforms and networks to induce and support synergies.

\section{Conclusions}

Our comparison of four tropical countries finds governance structures with strong relevance, but little support for agroforestry systems. Most existing incentives support agricultural practices that do not consider trees and biodiversity, and may even promote land-use change and deforestation of primary forests. Only few direct policy instruments and projects promote isolated biodiversity initiatives. In order to reduce harmful incentive systems (Aichi target 3) and to transform agricultural dynamics into sustainable conditions (Aichi target 7), existing incentive systems need to be changed. Our results point to three central entry insights to foster a transformative governance of agricultural landscapes.

Firstly, social and governmental perceptions of "good farming" need to include agroforestry to increase acceptance and accountability for sustainable farming. Even cattle ranchers in Honduras used to "clean" pastures and open lands are interested in the regulating ecosystem services of trees in the face of climate change and droughts. However, knowledge on context specific best practice options is scarce. 
Universities, research centres and NGOs, but also agricultural and forestry extension services can provide capacity building and demonstrate the ecosystem services provided by agroforestry, such as shade, wind breaks, fruit provision and (commercial) timber.

Secondly, implementation of agroforestry-specific instruments requires complementary structures providing regulation, finance, and information. Private initiatives (including carbon credits) and value chains, as well as local credit schemes support agriculture, but put significant hurdles to the application on agroforestry. Long-term tree investments are undermined by short time frames of credit schemes and difficult access conditions for remote farmers. Existing technological knowledge, related finance options as well as supporting regulatory frameworks need to be connected to political discourses in farming and to be linked to local governance structures to unleash the potential of agroforestry.

Thirdly, the different functions of actor groups need to be coordinated in facilitated learning processes. Farmer decisions are not only influenced by extension services, but also have to comply with requirements set by markets and credit institutes. The environmental sector responsible for implementing biodiversity targets and conserving habitat structures is badly disconnected from local structures. Existing platforms and cooperation schemes should be used to coordinate governmental and non-governmental efforts for joint implementation processes and institutional learning with a clear vision and mandate for agroforestry. Particularly bridging actors such as farmer associations and local governments play an important role in facilitating such processes.

Instead of supporting single selected executing partners in projects that target individual sustainability challenges, a closer focus on processes integrating the support for agroforestry across all relevant governance processes is necessary to foster adaptive learning of governance structures in order to achieve both biodiversity and climate targets. Looking at the dispersed and disconnected landscapes of projects and financial support we call for both public and private actors to continuously support these learning processes to both improve outcomes and use available funds more efficiently.

Acknowledgements Open Access funding provided by Projekt DEAL. We like to thank all Net-Map participants as well as the support of our partners in the four countries for their contributions to this study. This research received funding from the International Climate Initiative (IKI) (Grant number: BMUZ_1273). We like to thank the two reviewers for their very constructive comments.

Open Access This article is licensed under a Creative Commons Attribution 4.0 International License, which permits use, sharing, adaptation, distribution and reproduction in any medium or format, as long as you give appropriate credit to the original author(s) and the source, provide a link to the Creative Commons licence, and indicate if changes were made. The images or other third party material in this article are included in the article's Creative Commons licence, unless indicated otherwise in a credit line to the material. If material is not included in the article's Creative Commons licence and your intended use is not permitted by statutory regulation or exceeds the permitted use, you will need to obtain permission directly from the copyright holder. To view a copy of this licence, visit http://creativecommons.org/licenses/by/4.0/.

Open Access This article is licensed under a Creative Commons Attribution 4.0 International License, which permits use, sharing, adaptation, distribution and reproduction in any medium or format, as long as you give appropriate credit to the original author(s) and the source, provide a link to the Creative Commons licence, and indicate if changes were made. The images or other third party material in this article are included in the article's Creative Commons licence, unless indicated otherwise in a credit line to the material. If material is not included in the article's Creative Commons licence and your intended use is not permitted by statutory regulation or exceeds the permitted use, you will need to obtain permission directly from the copyright holder. To view a copy of this licence, visit http://creativecommons.org/licenses/by/4.0/.

\section{References}

Adelle C, Russel D (2013) Climate policy integration: a case of déjà vu? Environm Policy Govern 23(1):1-12. https://doi.org/10.1002/ eet. 1601

Ajayi OC, Place F (2012) Policy support for large-scale adoption of agroforestry practices: experience from Africa and Asia. In: Nair PR, Garrity D (eds) Agroforestry-the future of global land use. Springer, Dordrecht, pp 175-201

Ashley R, Russell D, Swallow B (2006) The policy terrain in protected area landscapes: challenges for agroforestry in integrated landscape conservation. Biodivers Conserv 15(2):663-689. https:// doi.org/10.1007/s10531-005-2100-x

Axelsson R, Angelstam P, Elbakidze M, Stryamets N, Johansson KE (2011) Sustainable development and sustainability: Landscape approach as a practical interpretation of principles and implementation concepts. J Landscape Ecol 4(3):5-30: https://doi. org/10.2478/v10285-012-0040-1

Bandiera O, Rasul I (2006) Social networks and technology adoption in northern Mozambique. Econom J 116:869-902. https://doi.org /10.1111/j.1468-0297.2006.01115.x

Barrios E, Sileshi GW, Shepherd K, Sinclair F (2012) Agroforestry and soil health: linking trees, soil biota, and ecosystem services. In: Wall D, Bardgett R, Behan-Pelletier V, Herrick J, Jones TH et al (eds) Soil Ecology and Ecosystem Services, vol 14. Oxford University Press, Oxford, pp 315-330

Bennett A, Ravikumar A, Cronkleton P (2018) The effects of rural development policy on land rights distribution and land use scenarios: the case of oil palm in the Peruvian Amazon. Land Use Policy 70:84-93. https://doi.org/10.1016/j.landusepol .2017.10.011

Berthet ET, Hickey GM (2018) Organizing collective innovation in support of sustainable agro-ecosystems: the role of network management. Agric Syst 165:44-54. https://doi.org/10.1016/j. agsy.2018.05.016

Bhattarai M, Hammig M (2004) Governance, economic policy, and the environmental Kuznets curve for natural tropical forests. Environ Dev Econ 9(3):367-382. https://doi.org/10.1017/S1355770X0 3001293

Bodin Ö, Crona BI (2009) The role of social networks in natural resource governance: what relational patterns make a difference? Global Environm Change 19(3):366-374. https://doi. org/10.1016/j.gloenvcha.2009.05.002 
Bourne M, Gassner A, Makui P, Muller A, Muriuki JA (2017) Network perspective filling a gap in assessment of agricultural advisory system performance. J Rural Stud 1(50):30-44. https://doi. org/10.1016/j.jrurstud.2016.12.008

Butts CT (2010) Tools for social network analysis, R package version, 2010, 2. https://CRAN.R-project.org/package =sna

CBD (1992) The Convention on Biological Diversity, United Nations Earth Summit, Rio de Janeiro, Brazil. https://www.cbd.int/conve ntion/text/

CBD (2010) Decision X/2_Strategic Plan for Biodiversity 2011-2020. In: Conference of the parties the convention for biological diversity, Nagoya, Japan. https://www.cbd.int/sp/elements/

Catacutan DC, Lasco RD, Piñon CD (2012) Incentive mechanisms for smallholder Agroforestry: opportunities and challenges in the Philippines. In: Nair PR, Garrity D (eds) Agroforestry-the future of global land use. Springer, Dordrecht, pp 497-514

Chiputwa B, Ihli HJ, Wainaina P, Gassner A (2020) Accounting for the invisible value of trees on farms through valuation of ecosystem services. In: Rusinamhodzi L (ed) The role of ecosystem services in sustainable food systems. Academic Press, pp 229-261. https://doi.org/10.1016/B978-0-12-816436-5.00012-3

Christiaensen L, Demery L (2018) Agriculture in Africa : telling myths from facts. Directions in development-agriculture and rural development. World Bank, Washington, DC. https://openknowle dge.worldbank.org/handle/10986/28543

Dawson IK, Guariguata MR, Loo J, Weber JC, Lengkeek A, Bush D, Cornelius J, Guarino L, Kindt R, Orwa C, Russell J (2013) What is the relevance of smallholders' agroforestry systems for conserving tropical tree species and genetic diversity in circa situm, in situ and ex situ settings? A review. Biodiver Conser 22(2):301-324. https://doi.org/10.1007/s10531-012-0429-5

Di Gregorio M, Nurrochmat DR, Paavola J, Sari IM, Fatorelli L, Pramova E, Locatelli B, Brockhaus M, Kusumadewi SD (2017) Climate policy integration in the land use sector: mitigation, adaptation and sustainable development linkages. Environ Sci Policy 67:35-43. https://doi.org/10.1016/j.envsci.2016.11.004

Dobie P, Zinngrebe Y, Vidal A, Gassner A, Kumar C (2019) Position on inclusion of agricultural lands as contributing to conservation of biodiversity in the post-2020 biodiversity agenda. Trees on Farms for Biodiversity programme, World Agroforestry, Nairobi, Kenia

Duit A, Hall O, Mikusinski G, Angelstam P (2009) Saving the woodpeckers: social capital, governance, and policy performance. J Environm Develop 18(1):42-61. https://doi.org/10.1177/10704 96508329302

Esparcia J (2014) Innovation and networks in rural areas. An analysis from European innovative projects. J Rural Studies 34:1-4. https ://doi.org/10.1016/j.jrurstud.2013.12.004

FAO (2005) Realising the benefits of agroforestry, State of the Worlds Forests, pp 88-97

FAO (2013) Advancing Agroforestry on the Policy Agenda: A guide for decision-makers, by Buttoud G, in collaboration with Ajayi O, Detlefsen G, Place F, Torquebiau E. Agroforestry Working Paper

FAO (2019) The State of the World's Biodiversity for Food and Agriculture, Bélanger J, Pilling D (eds.). FAO Commission on Genetic Resources for Food and Agriculture Assessments. Rome. 572 pp. URL: https://www.fao.org/3/CA3129EN/CA3129EN.pdf

Fagerholm N, Torralba M, Burgess PJ, Plieninger T (2016) A systematic map of ecosystem services assessments around European agroforestry. Ecol Ind 62:47-65. https://doi.org/10.1016/j.ecoli nd.2015.11.016

Galaz V, Crona B, Österblom H, Olsson P, Folke C (2012) Polycentric systems and interacting planetary boundaries - emerging governance of climate change-ocean acidification-marine biodiversity. Ecol Econ 1(81):21-32. https://doi.org/10.1016/j.ecole con.2011.11.012
HLPE (2019) Agroecological and other innovative approaches for sustainable agriculture and food systems that enhance food security and nutrition. A report by the High Level Panel of Experts on Food Security and Nutrition of the Committee on World Food Security, Rome

Hauck J, Schmidt J, Werner A (2016) Using social network analysis to identify key stakeholders in agricultural biodiversity governance and related land-use decisions at regional and local level. Ecol Soc 21(2):49. https://doi.org/10.5751/ES-08596-210249

Hauck J, Stein C, Schiffer E, Vandewalle M (2015) Seeing the forest and the trees: Facilitating participatory network planning in environmental governance. Global Environm Change 35:400-410. https://doi.org/10.1016/J.GLOENVCHA.2015.09.022

Hauck J, Schiffer E (2012) Between intuition and indicators - Using Net-Map for visual and qualitative social network analysis, In: Gamper M, Reschke L, Schönhuth M (eds.) Knoten und Kanten 2.0. Soziale Netzwerkanalyse in der Medienforschung und der Kulturanthropologie, Transcript, Bielefeld, pp 231- 257

Hogl K, Kleinschmit D, Rayner J (2016) Achieving policy integration across fragmented policy domains: forests, agriculture, climate and energy. Environm Plann C 34(3):399-414. https://doi. org/10.1177/0263774X16644815

IPBES (2019) Global Assessment Report on Biodiversity and Ecosystem Services of the Intergovernmental Science-Policy Platform, on Biodiversity and Ecosystem Services, Secretariat of the Intergovernmental Science-Policy Platform on Biodiversity and Ecosystem Services, Germany: Bonn

IUCN and WRI (2014) A guide to the Restoration Opportunities Assessment Methodology (ROAM): Assessing forest landscape restoration opportunities at the national or sub-national level. Working Paper (Road-test edition). Gland, Switzerland: IUCN, $125 \mathrm{pp}$

Isaac M, Matous P (2017) Social network ties predict land use diversity and land use change: a case study in Ghana. Reg Environ Change 17(6):1823-1833. https://doi.org/10.1007/s10113-017-1151-3

Isaac M, Erickson B, Quashie-Sam S, Timmer V (2007) Transfer of knowledge on agroforestry management practices: the structure of farmer advice networks. Ecol Soc 12(2):32. https://www.ecolo gyandsociety.org/vol12/iss2/art32/

Jordan A, Lenschow A (2010) Environmental policy integration: a state of the art review. Environm Policy Govern 20(3):147-158. https ://doi.org/10.1002/eet.539

Jose S (2009) Agroforestry for ecosystem services and environmental benefits. Agrofor Syst 76:1. https://doi.org/10.1007/s1045 7-009-9229-7

Karlsson-Vinkhuyzen S, Boelee E, Cools J, van Hoof L, Hospes O, Kok M, Peerlings J, van Tatenhove J, Termeer CJ, Visseren-Hamakers IJ (2018) Identifying barriers and levers of biodiversity mainstreaming in four cases of transnational governance of land and water. Environ Sci Policy 85:132-140. https://doi.org/10.1016/j. envsci.2018.03.011

Karlsson-Vinkhuyzen S, Kok MT, Visseren-Hamakers IJ, Termeer CJ (2017) Mainstreaming biodiversity in economic sectors: an analytical framework. Biol Cons 210:145-156. https://doi.org/10.1016/j. biocon.2017.03.029

Kassie GW (2018) Agroforestry and farm income diversification: synergy or trade-off? The case of Ethiopia. Environm Syst Res 6:8. https://doi.org/10.1186/s40068-017-0085-6

Larson AM, Pacheco P, Toni F, Vallejo M (2007) The effects of forestry decentralization on access to livelihood assets. J Environ Dev 16(3):251-68. https://doi.org/10.1177/1070496507306220

Laurance WF, Sayer J, Cassman KG (2014) Agricultural expansion and its impacts on tropical nature. Trends Ecol Evol 29(2):107-116. https://doi.org/10.1016/j.tree.2013.12.001 
Leigh Star S (2010) This is not a boundary object: Reflections on the origin of a concept. Sci Technol Human Values 35(5):601-617. https://doi.org/10.1177/0162243910377624

Lelong B, Stark M, Hauck J, Leuenberger T, Thronicker I (2016) A visual network perspective on social interaction and space: using net-map and wennmaker in participatory social-spatial research. Europa Regional 23(2):5-19

Lorenz K, Lal R (2014) Soil organic carbon sequestration in agroforestry systems. Rev Agron Sustain Develop 34(2):443-454. https ://doi.org/10.1007/s13593-014-0212-y

Magliocca NR, Rudel TK, Verburg PH, McConnell WJ, Mertz O, Gerstner K, Heinimann A, Ellis EC (2015) Synthesis in land change science: methodological patterns, challenges, and guidelines. Reg Environ Change 15(2):211-226. https://doi.org/10.1007/s1011 3-014-0626-8

Manolache S, Nita A, Ciocanea CM, Popescu VD, Rozylowicz L (2018) Power, influence and structure in Natura 2000 governance networks. A comparative analysis of two protected areas in Romania. J Environ Manage 212:54-64. https://doi.org/10.1016/j. jenvman.2018.01.076

Marjokorpi A, Ruokolainen K (2003) The role of traditional forest gardens in the conservation of tree species in West Kalimantan Indonesia. Biodivers Conser 12(4):799-822. https://doi. org/10.1023/A: 1022487631270

McAllister RR, Robinson CJ, Maclean K, Guerrero AM, Collins K, Taylor BM, De Barro PJ (2015) From local to central: a network analysis of who manages plant pest and disease outbreaks across scales. Ecol Soc. https://doi.org/10.5751/ES-07469-200167

Meinzen-Dick R, DiGregorio M, McCarthy N (2004) Methods for studying collective action in rural development. Agric Syst 82:197-214. https://doi.org/10.1016/j.agsy.2004.07.006

Moreno G, Aviron S, Berg S, Crous-Duran J, Franca A, de Jalón SG, Hartel T, Mirck J, Pantera A, Palma JHN, Paulo JA (2018) Agroforestry systems of high nature and cultural value in Europe: provision of commercial goods and other ecosystem services. Agrofor Syst 92(4):877-891. https://doi.org/10.1007/ s10457-017-0126-1

Morrison TH, Adger WN, Brown K, Lemos MC, Huitema D, Hughes TP (2017) Mitigation and adaptation in polycentric systems: sources of power in the pursuit of collective goals. Wiley Interdiscip Rev 8(5):e479. https://doi.org/10.1002/wcc.479

Noordwijk van M, ed (2019) Sustainable development through trees on farms: Agroforestry in its fifth decade. Bogor, Indonesia: World Agroforestry (ICRAF)

Nunan F, Campbell A, Foster E (2012) Environmental mainstreaming: the organisational challenges of policy integration. Public Admin Develop 32(3):262-277. https://doi.org/10.1002/ pad. 1624

Oosten C, Uzamukunda A, Runhaar H (2018) Corrigendum to Strategies for achieving environmental policy integration at the landscape level. A framework illustrated with an analysis of landscape governance in Rwanda. Environm Sci. https://doi. org/10.1016/j.envsci.2018.03.027

Ostrom E (2009) A general framework for analyzing sustainability of Social-Ecological Systems. Proc R Soc London Ser B 274:1931. https://doi.org/10.1126/science.1172133

Paavola J, Gouldson A, Kluvánková-Oravská T (2009) Interplay of actors, scales, frameworks and regimes in the governance of biodiversity. Environm Policy Govern 19(3):148-158. https:// doi.org/10.1002/eet.505

Persson Å, Runhaar H (2018) Conclusion: Drawing lessons for Environmental Policy Integration and prospects for future research. Environ Sci Policy 85:141-145. https://doi.org/10.1016/j.envsc i.2018.04.008
Pretty J, Smith D (2004) Social capital in biodiversity conservation and management. Conserv Biol 18(3):631-638. https://doi.org /10.1111/j.1523-1739.2004.00126.x

Pretty J, Toulmin C, Williams S (2011) Sustainable intensification in African agriculture. Inter J Agricul Sustain 9(1):5-24. https://doi. org/10.3763/ijas.2010.0583

Priess JA, Mimler M, Klein AM, Schwarze S, Tscharntke T, SteffanDewenter I (2007) Linking deforestation scenarios to pollination services and economic returns in coffee agroforestry systems. Ecol Appl 17(2):407-417. https://doi.org/10.1890/05-1795

Putnam R (2004) Democracies in flux: The evolution of social capital in contemporary society. Oxford University Press Inc, New York

Reed MS, Graves A, Dandy N, Posthumus H, Hubacek K, Morris J, Prell C, Quinn CH, Stringer LC (2009) Who's in and why? A typology of stakeholder analysis methods for natural resource management. J Environm Manag 90(5):1933-49. https://doi. org/10.1016/j.jenvman.2009.01.001

Rodríguez L, Cisneros E, Pequeño T, Fuentes M, Zinngrebe Y (2018) Building adaptive capacity in changing social-ecological systems: integrating knowledge in communal land-use planning in the Peruvian amazon. Sustainability 10(2):511. https://doi. org/10.3390/su10020511

Runhaar H, Wilk B, Driessen P, Dunphy N, Persson A, Meadowcroft J, Mullally G (2020) Policy integration. In: Biermann F, Kim RE (eds) Architectures of earth system governance: institutional complexity and structural transformation. Cambridge University Press, Cambridge

Saint Ville AS, Hickey GM, Locher U, Phillip LE (2016) Exploring the role of social capital in influencing knowledge flows and innovation in smallholder farming communities in the Caribbean. Food Secur 8(3):535-549. https://doi.org/10.1007/s12571-016-0581-y

Sanginga PC, Kamugisha RN, Martin AM (2007) The dynamics of social capital and conflict management in multiple resource regimes: a case of the southwestern highlands of Uganda. Ecol Soc 12(1):6

Sarkki S, Niemelä J, Tinch R, Jäppinen JP, Nummelin M, Toivonen H, Von Weissenberg M (2016) Are national biodiversity strategies and action plans appropriate for building responsibilities for mainstreaming biodiversity across policy sectors? The case of Finland. J Environm Plann Manag 59(8):377-1396. https://doi. org/10.1080/09640568.2015.1076384

Sayer J, Sunderland T, Ghazoul J, Pfund JL, Sheil D, Meijaard E, Venter M, Klintuni Boedhihartono A, Day M, Garcia C, van Oosten C, Buck LE (2013) Ten principles for a landscape approach to reconciling agriculture, conservation, and other competing land uses. Proc Natl Acad Sci 110(21):8349-8356. https://doi.org/10.1073/ pnas. 1210595110

Schiffer E, Hauck J (2010) Net-Map: collecting social network data and facilitating network learning through participatory influence network mapping. Field Methods 22:231-249. https://doi. org/10.1177/1525822X10374798

Schleyer C, Lux A, Mehring M, Görg C (2017) Ecosystem services as a boundary concept: arguments from social ecology. Sustainability 9(7):1107. https://doi.org/10.3390/su9071107

Schröter B, Sattler C, Graef F, Chen C, Delgadillo E, Hackenberg I, Halle EM, Hirt A, Kubatzki A, Matzdorf B (2018) Strengths and weaknesses of the Net-Map tool for participatory social network analysis in resource management: experience from case studies conducted on four continents. Methodol Innov 11(2):2059799118787754. https://doi.org/10.1177/2059799118 787754

Scobie M (2016) Policy coherence in climate governance in Caribbean small island developing states. Environ Sci Policy 58:16-28. https ://doi.org/10.1016/j.envsci.2015.12.008

Sears RR, Cronkleton P, Villanueva FP, Ruiz MM, del Arco MPO (2018) Farm-forestry in the Peruvian Amazon and the feasibility 
of its regulation through forest policy reform. Forest Policy Econom 87:49-58. https://doi.org/10.1016/j.forpol.2017.11.004

Somarriba E, Carreño-Rocabado G, Amores F, Caicedo W, de Pélichy SOG, Cerda R, Ordóñez JC (2017) Trees on farms for livelihoods, conservation of biodiversity and carbon storage: evidence from Nicaragua on this "invisible" resource. In: Montagnini F (ed) Integrating landscapes: agroforestry for biodiversity conservation and food sovereignty. Springer, Berlin, pp 369-393

Torralba M, Fagerholm N, Burgess PJ, Moreno G, Plieninger T (2016) Do European agroforestry systems enhance biodiversity and ecosystem services? A meta-analysis. Agr Ecosyst Environ 230:150 161. https://doi.org/10.1016/j.agee.2016.06.002

Valdivia C, Barbieri C, Gold MA (2012) Between forestry and farming: policy and environmental implications of the barriers to agroforestry adoption. Canadian J Agricul Econom Revue Canadienne d'agroeconomie 60(2):155-175. https://doi.org/10.111 $1 / \mathrm{j} .1744-7976.2012 .01248 . \mathrm{x}$
Wilson MH, Lovell ST (2016) Agroforestry - the next step in sustainable and resilient agriculture. Sustainability 8(6):574. https ://doi.org/10.3390/su8060574

Zinngrebe Yves M (2018) Mainstreaming across political sectors: Assessing biodiversity policy integration in Peru. Environm Policy Govern 28(3):153-171. https://doi.org/10.1002/eet.1800

Zomer RJ, Neufeldt H, Xu J, Ahrends A, Bossio D, Trabucco A, Van Noordwijk M, Wang M (2016) Global tree cover and biomass carbon on agricultural land: the contribution of agroforestry to global and national carbon budgets. Scient Rep 6:29987. https:// doi.org/10.1038/srep29987

Publisher's Note Springer Nature remains neutral with regard to jurisdictional claims in published maps and institutional affiliations. 